\title{
Green Infrastructure in Coastal Landscapes: Hydrological Function, Ecological Design and Sustainable Land Use Guidance
}

\author{
Daniel R. Hitchcock ${ }^{1}$, Anand D. Jayakaran ${ }^{1}$ and David L. White ${ }^{2}$
}

\begin{abstract}
AUTHORS: ${ }^{1}$ School of Agricultural Forest \& Environmental Sciences, Clemson University, Baruch Institute of Coastal Ecology and Forest Science, PO Box 596, Georgetown, South Carolina 29442. ${ }^{2}$ Clemson Computing and Information Technology (CCIT), Clemson, South Carolina 29634.

REFERENCE: Proceedings of the 2012 South Carolina Water Resources Conference, held October 10-11, 2012 at the Columbia Metropolitan Convention Center.
\end{abstract}

\begin{abstract}
Coastal landscape modification, specifically the conversion of forests to residential and commercial development, coupled with potential climate change impacts, could lead to irretrievable natural resource impairment. An assessment of existing resources (green infrastructure) and their benefits via ecosystem services provides useful guidance for resource protection to enhance community resilience. These landscape elements are complex within and between varying scales; therefore stakeholders need clear, relevant, comparable, and easily accessible information for effective decision-making.

In this paper, we discuss hydrological and ecological parameters that could guide sustainable land use in coastal South Carolina. Analyses have been conducted in watersheds with low gradient topography and shallow water table conditions to define pre-development conditions. We also investigate hydrologic and hydraulic performance of vegetated stormwater control measures - specifically infiltrationbased bioretention systems - in these coastal areas with frequently limited infiltration capacity. Results from these analyses are being integrated into an online mapping tool so that geospatial data variability complement research efforts, and vice versa, while also providing site-specific information to land and water resource decision-makers.
\end{abstract}

\section{BACKGROUND AND RELATED WORK}

In South Carolina, low gradient coastal watersheds with shallow water tables are often prone to flooding and water quality impairments, especially where urbanization has occurred (Tufford et al., 2003;
Holland et al., 2004). Seasonally variable groundwater position (Figure 1) plays a substantial role in the ratio of rainfall to discharge and runoff volume (Sun et al., 2002; Amatya et al., 2006; Harder et al., 2007; La Torre Torres et al., 2011; Epps 2012; Epps et al., 2013a; Epps et al., 2013b). The mechanism by which runoff is generated can and should dictate what stormwater control measures (SCMs) are implemented and how they are designed, specifically toward the goals of reductions in both peak flow rate and total discharge volume.

Green infrastructure has been defined as "an interconnected network of natural areas and other open spaces that conserves natural ecosystem values and functions, sustains clean air and water, and provides a wide array of benefits to people and wildlife". (Benedict and McMahon, 2006). Recent focus on green infrastructure by the U.S. EPA as a measure for "managing wet weather" includes a subset of technologies known as Low Impact Development (LID). EPA-recommended site-scale practices include rainwater harvesting, downspout disconnection, rain gardens, permeable pavements, vegetated swales, green roofs, and brownfield and infill redevelopment. Neighborhood-scale approaches include "green" parking, streets, and highways; pocket wetlands, and urban forestry strategies. Watershed scale strategies include riparian buffers (U.S. EPA, 2010a). Many of these strategies are further explored in a sustainable design and green building toolkit for local governments (U.S. EPA, 2010b). From a stormwater regulatory standpoint, anticipated changes to the NPDES permit requirements both nationwide and within South Carolina are moving toward volume- and infiltrationbased strategies in contrast to the current requirements 


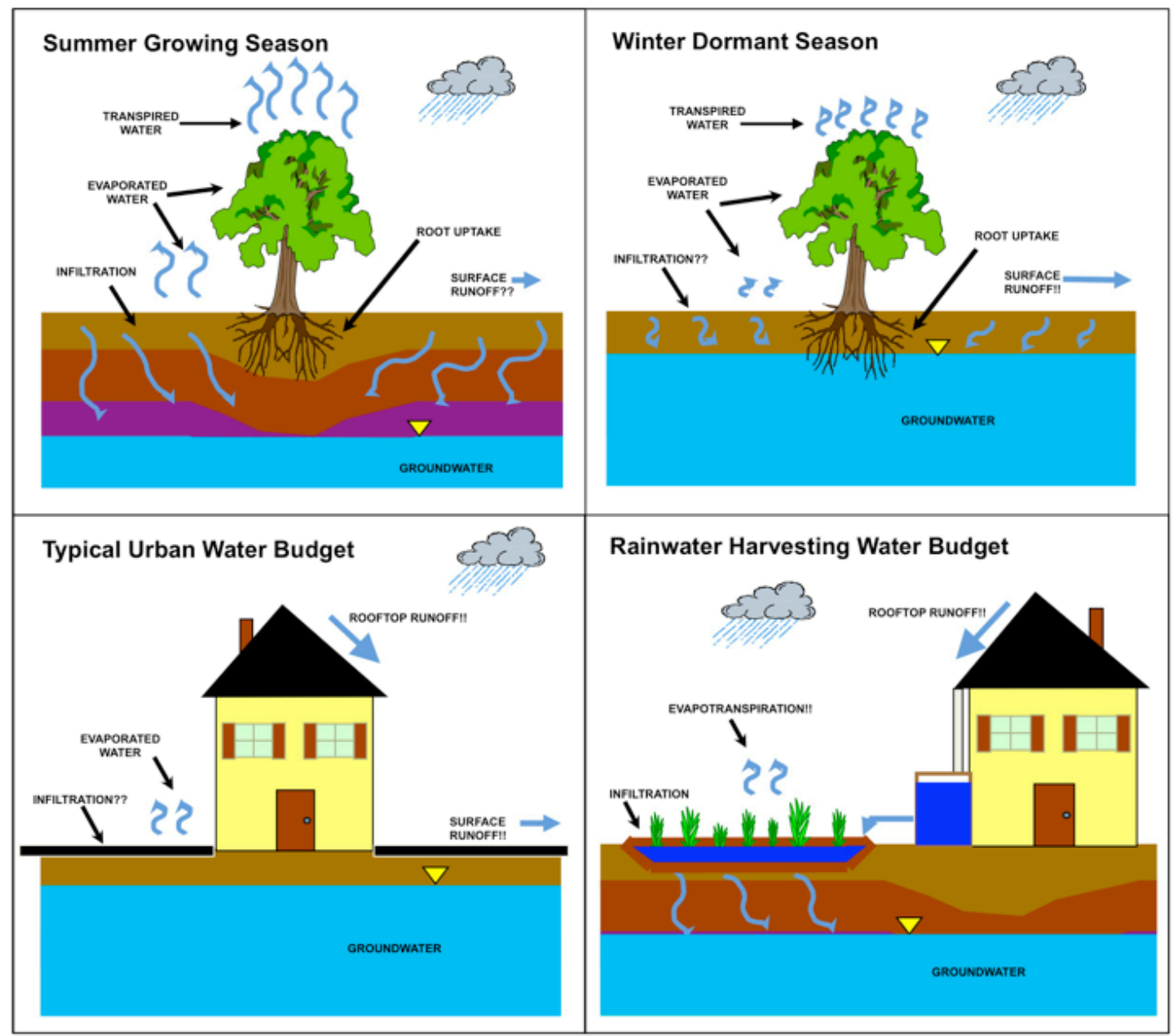

Figure 1. Conceptual water budgets for forested versus urban systems, including seasonally variable groundwater elevations (top panels) for pre-development conditions, and an impervious surface scenario compared to a rainwater harvesting system (bottom panels) based on green infrastructure design principles.

where post-development peak flows must at least equal those of pre-development. As these mandates move forward, local and regional decision-makers and land use practitioners need science-based tools to inform the design process.

From a larger conceptual view of green infrastructure, we can summarize landscape design goals as follows:

- retain the natural landscape and hydrology;

- promote open space, corridor, and habitat preservation;

- encourage riparian and floodplain protection;

- reduce and disconnect impervious surfaces; and

- provide on-site stormwater management and water re-use.

Potential short- and long-term adverse impacts from coastal land use change can be reduced by informed decision-making at various scales, especially if targets for sustainable solutions are well defined. Whether the effort is one of preservation or restoration (or both), the integrated yet often highly variable system components of water, soils, and vegetation - as well as respective processes within the landscape - must be incorporated into the strategy. The preservation and/or enhancement of ecosystem services should optimize sustainable land use and water resource protection strategies. This work will identify sustainable land use practices and natural resource preservation strategies given available landscape information based on a natural resource inventory. The project also seeks to develop sciencebased tools to inform the decision-making process related to green infrastructure.

\section{PROJECT DESIGN}

We utilize a growing understanding of coastal forested hydrologic processes and ecological engineering design principles to provide information to land and water resource decision-makers, not only 
with respect to effective stormwater management, but also toward the preservation and restoration of coastal ecohydrological services. Achieving pre-development flows under the post-construction scenario is a regulatory requirement, but this is usually accomplished with a hydrographic assessment typically conducted by watershed modeling (curve number based TR-55) (Epps et al., 2013b). However, an understanding of associated water budgets (Figure 1) that represents seasonal variability would better guide targeted sitespecific development strategies. Proper stormwater management practice selection, siting, and sizing depends on whether the practice functions primarily via evapotranspiration, infiltration, retention, reuse, or a combination of these processes.

A landscape-based decision making approach can be complicated by multi-scale factors, creating a need for process-based information among varying spatial and temporal scales. Spatial scales can include the individual or series ("treatment train") of SCMs, the development tract, and the watershed or river basin scale. Temporal scales include daily (storm-event), seasonal and annual (water table fluctuation), multiyear and even decadal (climate variability). Planners, engineers, and regulators need to incorporate spatial and temporal scale information into effective land use decision-making.

\section{Coastal Stormwater Control Measures}

Infiltration-based rain garden and bioretention systems are gaining popularity for use in coastal locations (Figure 2). However, due to shallow groundwater influence and thus frequent wet conditions - especially in winter months - many of these systems are hydrologically and ecologically converting into retention-based wetland systems, performing differently than originally intended. Coastal proximity and thus the potential for shallow groundwater can play a significant role in system performance.

Ongoing investigations seek to better understand the connection between surface and groundwater quantity and quality associated with these vegetated SCMs (bioretention and wetlands), as well as the interaction of these processes under varying landscape parameters (sandy versus clayey soils, SCM elevation, depth to seasonally high water table, proximity to tidal surfaces waters) and drainage area features (impervious surface percentages, slope, time to concentration, etc.). An example is the Clemson - Baruch bioretention demonstration site (Figure 2) where rooftop runoff is being collected and managed. This site exhibits the other end of the hydrologic spectrum compared to the bioretention-conversion-to-wetland scenario previously

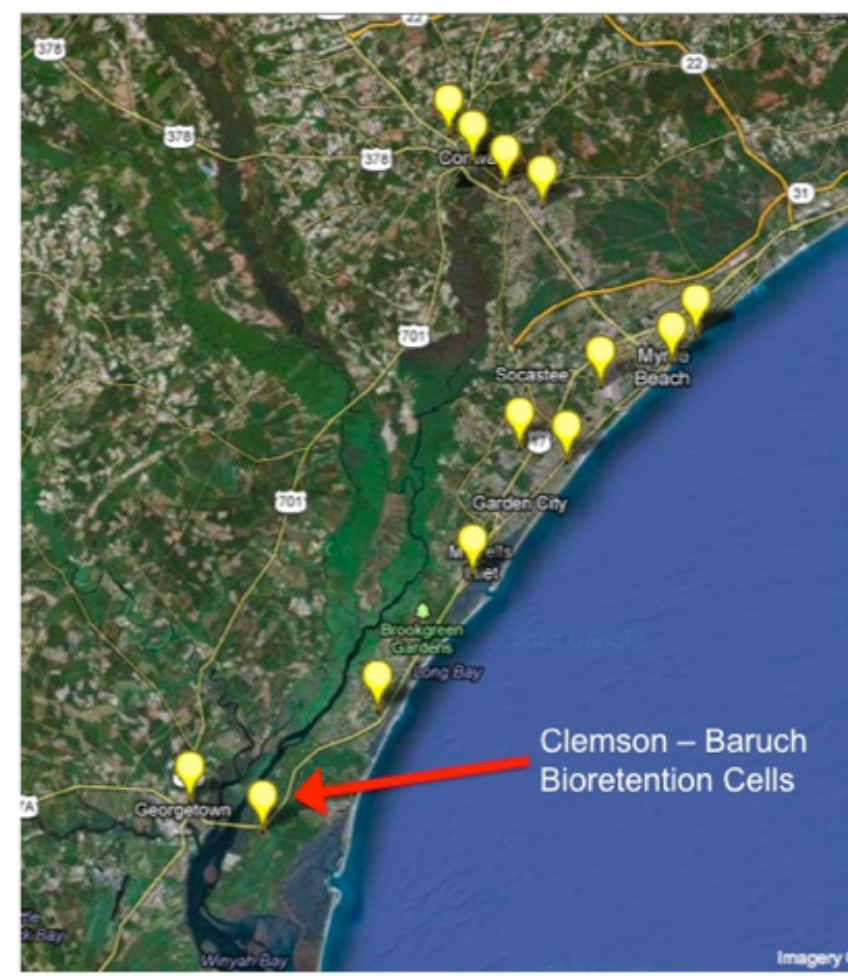

Figure 2. Locations of rain garden and bioretention in coastal Horry and Georgetown Counties indicated by yellow markers (from the SC LID Atlas and the National NEMO Network - not all are included - visit http://www.clemson.edu/public/carolinaclear/

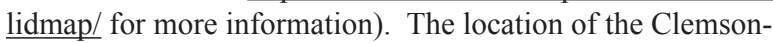
Baruch Institute bioretention demonstration site is highlighted.

described. The bioretention system was installed in 2009 on Lakeland soil (excessively well-drained sand). Parameters being monitored include rainfall, ambient air temperature, relative humidity, solar radiation, and water table position, as well as soil moisture (as volumetric water content) within a vertical profile below the bioretention cell bottom. The seasonally high water table depth is at approximately $1.0 \mathrm{~m}$ below ground surface (bgs). A snapshot of data is provided in Figure 3 illustrating the response of groundwater elevation to rain events. The quick response of soil moisture reflects a water flux characterized by extremely rapid infiltration rates as well as a rapid decline in available soil water. Further analyses of these data and water quality data for the Clemson-Baruch bioretention cells and others in coastal South Carolina are currently underway.

\section{Geospatial Reference, Variability and Assessment}

An online Community Resource Inventory (CRI) (screen grab shown in Figure 4) has been piloted by the S.C. Sea Grant Extension Program and Clemson University in lower coastal plain of Georgetown County, South Carolina, with some expanded information for Horry County (http://maps.clemson.edu/cri/index.html) (including the greater urbanized area of Myrtle Beach). 


\begin{tabular}{l} 
Clemson - Baruch Weather \\
Rain: $0.00 \mathrm{in}$ \\
(2) Pressure: $30.047 \mathrm{inHg}$ \\
Temperature: $71.96^{\circ} \mathrm{F}$ \\
Dew Point: $71.33^{\circ} \mathrm{F}$ \\
(2) PAR: $441 \mathrm{uE}$ \\
\hline Solar Radiation: $168 \mathrm{~W} / \mathrm{m}^{2}$ \\
Battery: $4.48 \mathrm{~V}$ \\
\hline
\end{tabular}

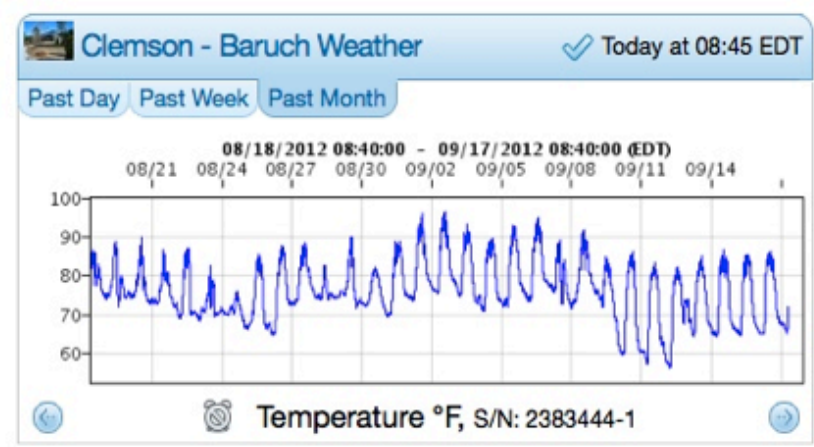

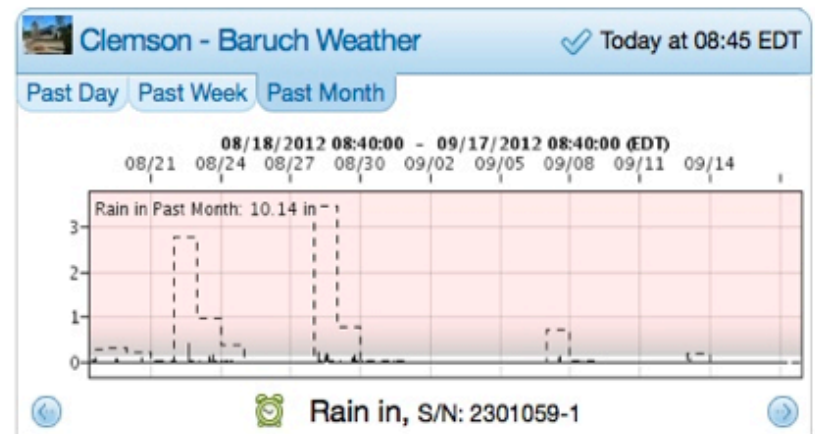

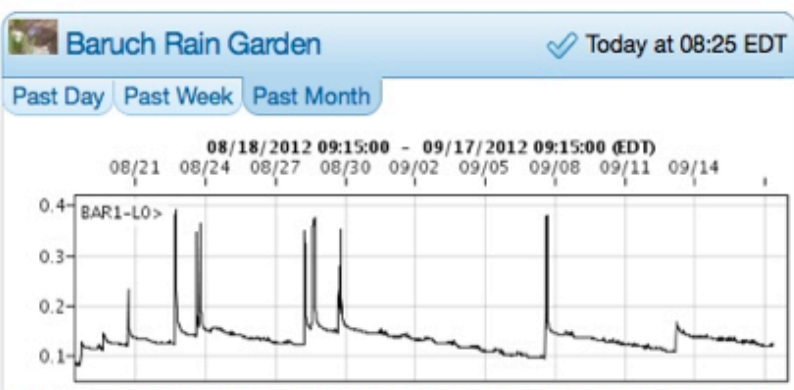

(4) (8) Water Content (BAR1-LO>) $\left.\mathrm{m}^{3} / \mathrm{m}^{3}, \mathrm{~S} / \mathrm{N}: 9756597-1\right)$

Figure 3. Sample screenshot of meteorological and hydrographic data from the Clemson-Baruch rain gardens (http://www.clemson. $\mathrm{edu} / \mathrm{public} / \mathrm{rec} / \mathrm{baruch} / \mathrm{rain}$ gardens.html). A subset of all data including real-time weather parameters (top left), ambient air temperature (bottom left), rainfall (top right) and surface soil moisture content (bottom right) are shown respectively.

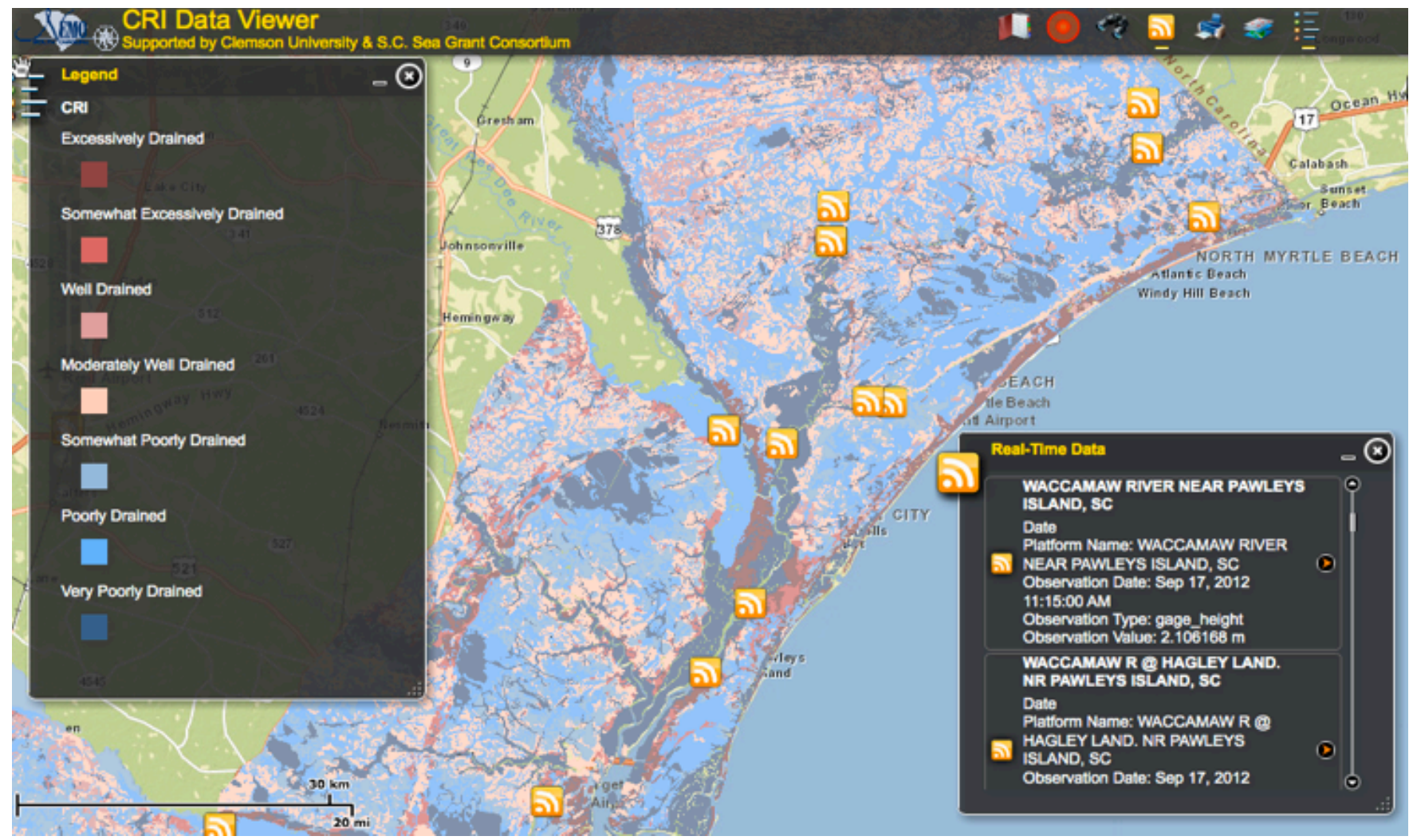

Figure 4. Online Community Resource Inventory (CRI) depicting soil drainage classes (with legend) and real-time access to USGS water resources data for coastal Horry and Georgetown Counties (http://www.cri-sc.org). 

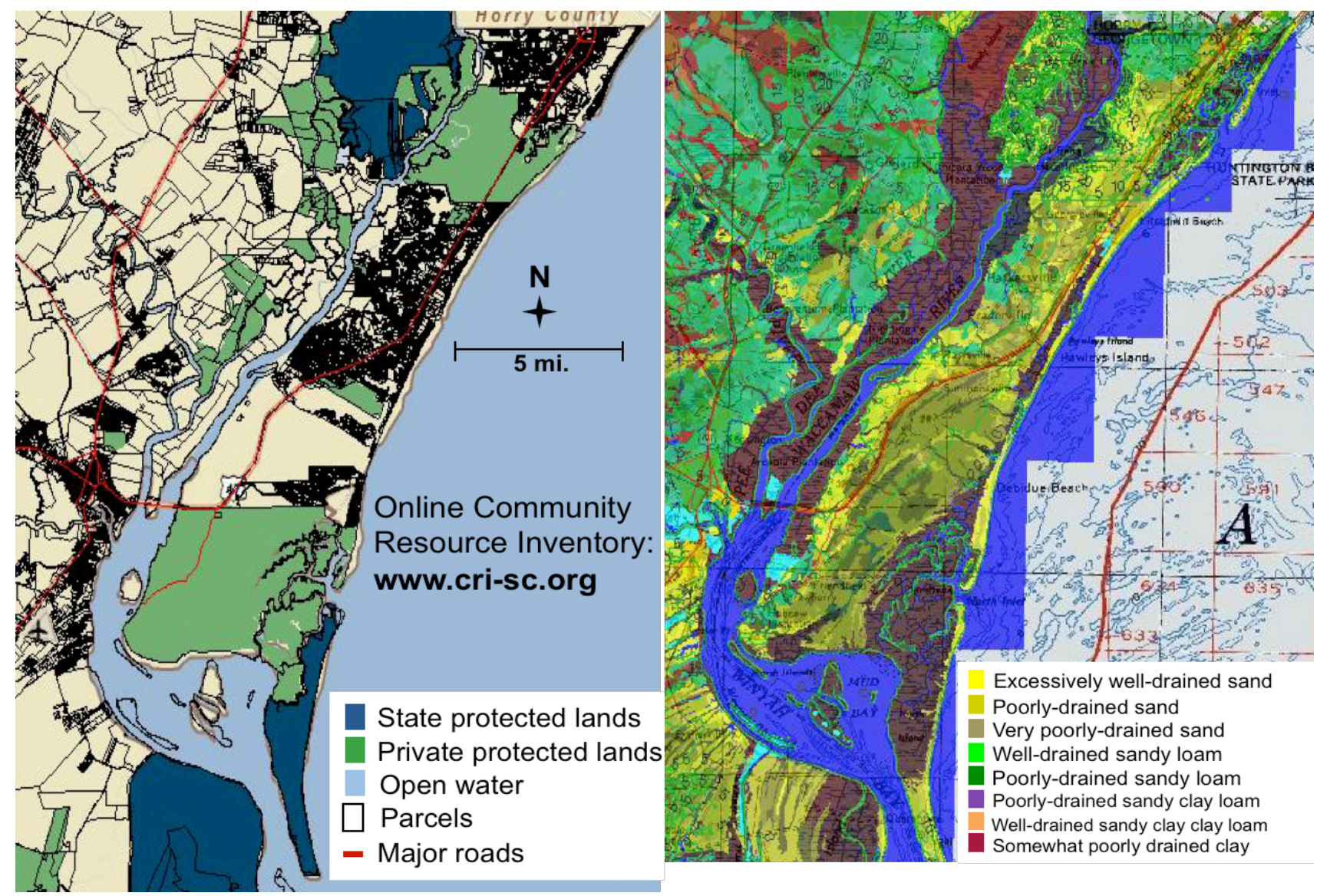

Figure 5. Map outputs from the Online Community Resource Inventory (CRI) for Georgetown County, SC, focusing on the Waccamaw Neck. Property ownership (parcels and protected lands) information overlays a street map for natural resource planning and zoning (left) and soil drainage class information overlays a USGS topo map to be used for stormwater management plan reviews and decision-making (right).

Data layers can be viewed over street maps, aerial imagery, or topographic maps, and include elevation, soils, land use/land cover, impervious surfaces, parcels, zoning, protected lands, watersheds, impaired waters, and flood zones, among others (Hitchcock et al., 2010). Real-time data can be viewed as RSS feed portals in the mapping tool. Currently only USGS data links are available online, but efforts are underway to populate the tool with data collected from SCM investigations

Figure 5 shows a sample view of the CRI for coastal Georgetown County (image modified by addition of legends). The tool provides multiple data layers that can be useful to site design professionals and stormwater plan reviewers, among others. As Low Impact Development (LID) practices based on green infrastructure are becoming more popular, the geospatial tool can aid users by providing SCM practice information, including site parameters and landscape features. The tool is being modified to include a SCM suitability and feasibility layer based on geospatial landscape and hydrologic data. An extended use of the tool may include the capability to inform planning and zoning processes with parcel information, impervious surface areas, public and protected land areas, land use/ land cover data, and habitat designations.

In Figure 6, water quality impairments can be identified using the mapping tool, in this case showing fecal coliform impairments from the 2010 SCDHEC 303(d) list, including shellfish monitoring locations as well as TMDL status for coastal waters of Georgetown County and southern Horry County. Land cover data are also shown. Such geospatial information can be useful for the prioritization of stormwater management efforts, as well as sustainable land use and decisionmaking for improved water resource protection. As the tool continues to be improved, the geospatial and real-time hydrologic data along with water quality impairment information may have the capacity to guide future conservation and restoration activities. 


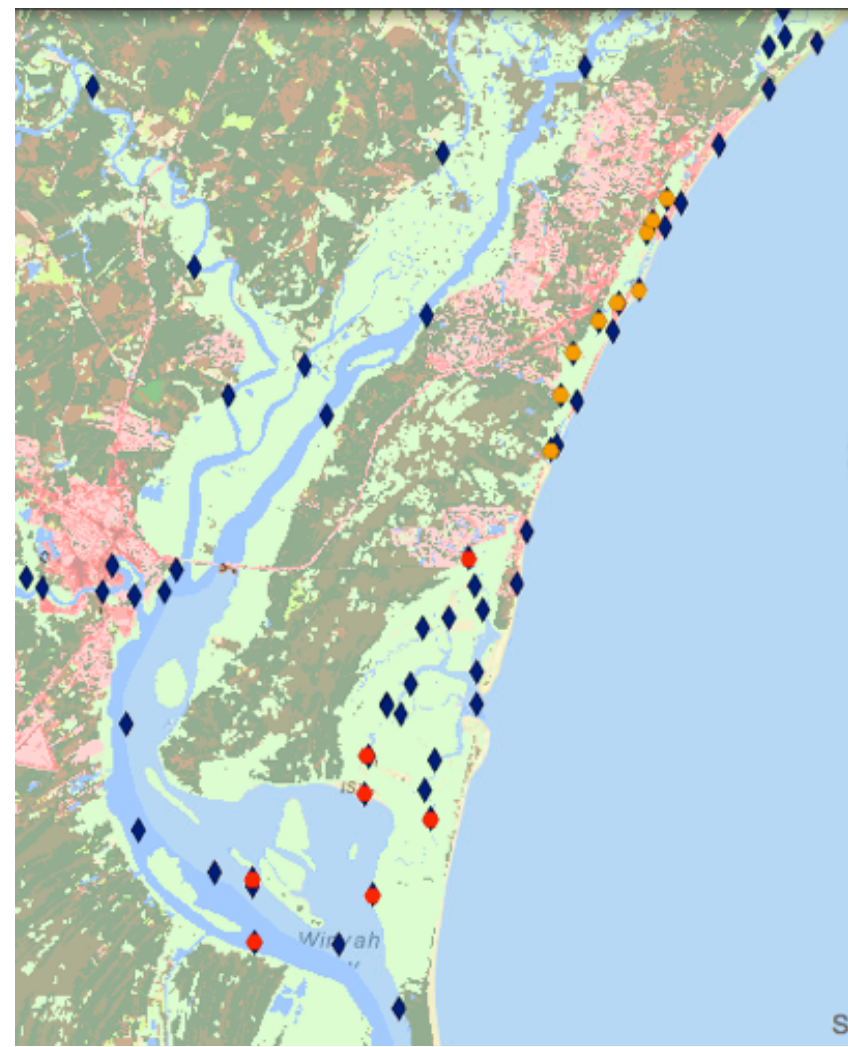

Figure 6. SCDHEC 303(d)-listed water quality impairment sites (2010) (blue diamonds $=$ all coastal monitoring stations, red diamonds = impaired fecal shellfish sites, orange diamonds = impaired fecal shellfish sites with TMDL) and National Land Cover Database (2006) data (light green $=$ emergent wetlands, dark green $=$ forests, light pink $=$ low density developed lands and dark pink $=$ medium density developed lands).

\section{FUTURE GOALS AND DIRECTIONS}

Geospatially referenced data, including a reliable inventory of site-specific conditions, are pertinent to performance-based selection and/or enhancement of SCMs for effective stormwater management, especially those measures that rely on existing or newly installed green infrastructure. Increased utility of geospatial information for resource inventory and better understanding of relationships to ecosystem services - here specifically stormwater quality and quantity management - will be accomplished as follows via the online CRI tool: (1) extrapolate rainfall-runoffwater table relationships and curve numbers (Epps et al., 2013a; Epps et al., 2013b) for a larger geospatial area; (2) introduce SCM (bioretention and wetland) monitoring data into the CRI tool as RSS feeds; (3) develop criteria for SCM suitability and feasibility based on geospatial data, specifically soils and topography, as well as groundwater elevation data and existing land use/cover; (4) incorporate SCM suitability and feasibility indices into mapping layers for increased function of the CRI tool; and (5) assess longer term implications as related to climate variability, sea level rise, higher water table elevations, and more extreme temperature and precipitation regimes.

As investigations into the role of green infrastructure in sustainable land use and water resource protection continues, the resulting science-based information will be relevant, accessible, and meaningful for effective land use planning and stormwater infrastructure decision-making over multiple spatial and temporal scales in coastal South Carolina.

\section{ACKNOWLEDGEMENTS}

Very special thanks to Samantha Bruce and April Turner (S.C. Sea Grant Consortium), Jeff Vernon (Clemson-Baruch Institute), and Dawn White (Clemson University Center for Watershed Excellence, Institute of Computational Ecology) for their continued assistance with online CRI development. This work was sponsored by the S.C. Sea Grant Consortium with NOAA financial assistance awards No. NA06OAR4170015 and NA10OAR4I70073. The online CRI was sponsored by a cooperative agreement between the University of Connecticut and the S.C. Sea Grant Consortium. This work was partially supported by Clemson University's Public Service Activities (PSA). Other support was provided by the Carolina Clear program and the Center for Watershed Excellence, both administered through Clemson University and the Clemson Experiment Station.

\section{REFERENCES}

Amatya, D.M., M. Miwa, C.A. Harrison, C.C. Trettin and G. Sun, 2006. Hydrology and water quality of two first order forested watersheds in coastal South Carolina. ASABE Paper no: 062182, St. Joseph, Mich.:ASABE, 22 pp.

Benedict, M. A., and E. T. McMahon. 2006. Green Infrastructure: Linking Landscapes and Communities. Island Press, 299 pp.

Epps, T. H. 2012. Assessment of the rainfall response of headwater streams in lower coastal plain South Carolina. Masters thesis, Biosystems Engineering program, Clemson University. May, 2012.

Epps, T. H., D. R. Hitchcock, A. D. Jayakaran, D. R. Loflin, T. M. Williams, and D. M. Amatya. 2013a. Characterization of storm flow dynamics 
of headwater streams in the South Carolina lower coastal plain. Journal of the American Water Resources Association 49(1):76-89.

Epps, T. H., D. R. Hitchcock, A. D. Jayakaran, D. R. Loflin, T. M. Williams, and D. M. Amatya, 2013b. Curve number method assessment for two headwater streams in lower coastal plain South Carolina, USA. Journal of American Water Resources Association, 49(6):1284-1295.

Harder, S., D. Amatya, T. Callahan, C. Trettin, and J. Hakkila, 2007. Hydrology and water budget for a forested Atlantic coastal plain watershed, South Carolina. Journal of the American Water Resources Association 43(3):563-575.

Hitchcock, D.R., D.L. White, A.D. Jayakaran, T.M. Williams, K. Giacalone, J. Calabria, C.B. Sawyer, and G.W. Eidson. 2010. Green infrastructure assessment tools for varying scales in coastal South Carolina. In: Eidson, G.W. and Sawyer, C.B., eds., Proceedings of the 2010 South Carolina Water Resources Conference, October 13-14, Columbia, SC.

Holland, A.F., D. Sanger, C. Gawle, S. Lerberg, M. Santiago, G. Riekerk, L. Zimmerman, and G. Scott. 2004. Linkages between tidal creek ecosystems and the landscape and demographic attributes of their watersheds. Journal of Experimental Marine Biology and Ecology 298(2):151-178.

La Torre Torres, I.B., D.M. Amatya, G. Sun, and T.J. Callahan. 2011. Seasonal rainfall-runoff relationships in a lowland forested watershed in the southeastern USA. Hydrological Processes 25:2032-2045.

Sun, G., S.G. McNulty, D.M. Amatya, R.W. Skaggs, L.W. Swift, J.P. Shepard, and H. Riekerk, 2002. A comparison of the watershed hydrology of coastal forested wetlands and the mountainous uplands in the southern US. Journal of Hydrology 263:92-104.

Tufford, D.L., C.L. Samarghitan, H.N. McKellar Jr., D.E. Porter, J.R. Hussey. 2003. Impacts of urbanization on nutrient concentrations in small southeastern coastal streams. Journal of the American Water Resources Association 39(2):301-312.

U.S. EPA. 2010. Managing Wet Weather with Green Infrastructure. Accessed Sept. 17, 2012. http://water. epa.gov/infrastructure/greeninfrastructure/index.cfm. 